\title{
PERANCANGAN SISTEM PENILAIAN KINERJA PEGAWAI PADA PDAM TIRTA PATRIOT BEKASI MENGGUNAKAN NETBEANS
}

\author{
Krisdiyono $^{1}$, Millati Izzatillah ${ }^{2}$, Andreas Adi Trinoto ${ }^{3}$ \\ 1,2Teknik Informatika, Universitas Indraprasta PGRI \\ Jl. Raya Tengah, Gedong, Pasar Rebo, Jakarta Timur \\ ${ }^{1}$ xeeterponija@gmail.com, ${ }^{2}$ mizzatillah@gmail.com, ${ }^{3}$ a.trinoto@gmail.com
}

\begin{abstract}
ABSTRAK
Saat ini, Perusahaan Daerah Air Minum (PDAM) Tirta Patriot di kota Bekasi masih menggunakan cara manual dalam proses penilaian kinerja pegawai yaitu dengan menulis nilai dengan kertas formulir penilaian kemudian dipindahkan ke microsoft excel untuk dilakukan perhitungan nilai. Proses penilaian ini memerlukan banyak waktu dan kemungkinan besar terjadi kesalahan dalam memasukan nilai sehingga hal ini dianggap kurang efektif dan efisien. Tujuan merancang sebuah sistem penilaian kinerja pegawai adalah untuk memudahkan dalam melakukan penilaian pegawai berdasarkan bobot dan kriteria-kriteria penilaian yang telah ditentukan oleh perusahaan. Dengan menggunakan metode pengembangan sistem yaitu Waterfall dalam penelitian ini dengan tahapan-tahapan seperti rekayasa sistem, analisis, desain, implementasi, uji coba, dan pemeliharaan. Hasil akhir dari penelitian ini adalah merancang aplikasi yang bisa melakukan penilaian kinerja pegawai secara terkomputerisasi dan membantu pekerjaan admin bagian kepegawaian dalam membuat laporan yang tersimpan dengan baik serta memberikan hasil secara cepat dan akurat.
\end{abstract}

Kata Kunci: penilaian, kinerja, berbasis loyalitas

\begin{abstract}
Currently, the Regional Drinking Water Company (PDAM) Tirta Patriot in the city of Bekasi is still using the manual method in the employee performance appraisal process, namely by writing the value with an assessment form paper and then transferring it to Microsoft Excel to calculate the value. This assessment process takes a lot of time and there is a high possibility of errors in entering values so that it is considered less effective and efficient. The purpose of designing an employee performance appraisal system is to make it easier to evaluate employees based on weights and assessment criteria that have been determined by the company. By using the system development method, namely Waterfall in this research with stages such as systems engineering, analysis, design, coding, testing, and maintenance. The final result of this research is to design an application that can perform a computerized employee performance assessment and assist the work of the staffing admin in making reports that are stored properly and provide results quickly and accurately.
\end{abstract}

Key Word: Assessment, Performance, loyalty based

\section{PENDAHULUAN}

Setiap perusahaan maupun instansi pemerintahan memerlukan sebuah sistem yang tepat untuk menunjang kelangsungan kegiatan dan kinerja pegawai untuk mencapai sasaran atau tujuannya. Maka dari itu, untuk mengetahui kemampuan pegawai dalam mengerjakan tugas yang diberikan oleh perusahaan, maka dilakukan penilaian kinerja pegawai.

Fathansyah (2012) menyatakan bajwa Sistem ialah sebuah keterpaduan atau tatanan yang terdiri dari beberapa komponen fungsional (dengan satuan tugas atau fungsi khusus ) dan saling berhubungan secara bersama-sama yang mempunyai tujuan untuk memenuhi suatu pekerjaan atau proses tertentu. Sedangkan Azhar Susanto (2013) menyatakan bahwa Sistem adalah kumpulan / group dari sub sistem/komponen apa saja baik fisik maupun non fisik yang saling berhubungan satu dengan yang lain dan saling bekerja sama secara terpadu untuk mencapai tujuan tertentu. Yakub (2012) menyatakan bahwa Perancangan Sistem didefinisikan sebagai perencanaan, pembuatan dan penggambaran sketsa ataupun pengaturan beberapa elemen yang terpisah menjadi kesatuan yang berfungsi secara utuh.

Kinerja merupakan prestasi atau pencapaian seseorang yang berkenaan dengan pekerjaan yang diberikan kepadanya (Marwansyah, 2016). Sedangkan Moeheriono (2012) menyatakan bahwa kinerja merupakan suatu gambaran tentang tingkatan dari pencapaian 
pelaksanaan suatu kebijakan atau program kegiatan dalam mencapai sasaran, misi dan tujuan organisasi yang dituangkan dalam perencanaan strategis di suatu organisasi.

Penilaian prestasi kerja adalah menilai rasio dari hasil kerja nyata dengan suatu standar kuantitas maupun kualitas yang dihasilkan setiap pegawai. Menetapkan suatu kebijaksanaan yang berarti apakah seorang pegawai akan dipromosikan, didemosikan, dan atau balas jasanya dinaikkan (Malayu S.P. Hasibuan, 2017). Penulis mengambil kesimpulan bahwa penilaian kinerja merupakan upaya untuk menilai suatu prestasi yang bertujuan untuk meningkatkan produktivitas pegawai maupun perusahaan. Namun, tujuan itu terkadang tidak tercapai karena kurang baiknya penilaian kinerja yang dilakukan oleh perusahaan. Dampak yang terjadi adalah turunnya motivasi kerja pegawai dan pencapaian target perusahaan tiap tahun.

Pada Perusahaan Daerah Air Minum (PDAM) Tirta Patriot Kota Bekasi dalam penilaian kinerja pegawai masih menggunakan penilaian yang bersifat manual yaitu bagian kepegawaian memberikan kertas formulir penilaian pegawai ke pejabat penilai. Kemudian pejabat penilai menilai pegawai bawahannya dengan mencatat di kertas formulir penilaian pegawai. Setelah dinilai, bagian kepegawaian memasukan hasil penilaian ke dalam arsip pembukuan. Lambatnya proses penilaian dan kelengkapan data pegawai mengakibatkan keterlambatan dalam memberikan laporan penilaian pegawai.

Oleh karena itu, tujuan penulis melakukan penelitian ini adalah membuat suatu sistem penilaian pegawai yang mudah digunakan secara terkomputerisasi dan membuat suatu laporan dapat lebih cepat, akurat dan mudah. Kegunaan penelitian yang diberikan dalam tugas akhir ini adalah membantu Admin bagian Kepegawaian dalam melakukan penilaian kinerja, dapat menyajikan laporan yang cepat, tepat dan akurat, berguna untuk pengembangan sistem penilaian kinerja untuk pegawai di masa yang akan datang. Kegunaan bagi Penulis untuk syarat kelulusan S1. Kegunaan bagi mahasiswa, penelitian ini dapat memberikan pengetahuan dan sebagai referensi bagi mahasiswa yang melakukan penelitian dengan permasalahan yang sama.

\section{METODE PENELITIAN}

Tempat Penelitian dilakukan pada Perusahaan Daerah Air Minum (PDAM) Tirta Patriot Kota Bekasi yang beralamatkan di Jl. Perjuangan No. 99 Kel. Margamulya, Kec.

Bekasi Utara, Kota Bekasi.

Desain yang digunakan dalam penelitian ini yaitu metode air terjun atau yang sering disebut metode waterfall. Metode ini sering diberi nama siklus hidup klasik, dimana dalam hal ini menggambarkan suatu pendekatan yang berurutan dan juga sistematis pada pengembangan perangkat lunak, dimulai dari kebutuhan spesifikasi si pengguna lalu berlanjut melalui suatu tahapantahapan perencanaan (planning), permodelan (modeling), konstruksi (construction), serta penmberian sistem kepada pengguna (deployment), diakhiri dengan memberikan dukungan pada perangkat lunak yang dihasilkan secara lengkap (Pressman, 2012).

Dalam pengumpulan data penulis menggunakan teknik dalam pengumpulan data untuk penelitian antara lain:

\section{Studi kepustakaan}

Data dan informasi dikumpulkan dari kutipankutipan buku-buku, artikel jurnal, hasil laporan dan bahan lainnya yang berkaitan dengan penelitian ini. Dari bahan-bahan tersebut kemudian diambil teori-teori yang dapat dijadikan suatu landasan untuk menganalisa masalah yang terjadi didalam penelitian.

\section{Studi Lapangan}

Pada Studi lapangan, penulis melihat langsung sistem penilaian kinerja pegawai yang menggunakan sistem manual (mencatat dengan tangan). Dalam studi lapangan penulis menggunakan teknik pengumpulan data antara lain dengan cara: Wawancara yaitu teknik pengumpulan data dengan bertanya langsung kepada pegawai PDAM yang mengerti dan paham mengenai proses penilaian kinerja pegawai. Metode wawancara merupakan metode yang sangat efektif dalam pengumpulan data. Penulis melakukan wawancara terhadap admin bagian kepegawaian untuk mendapatkan data-data seperti data pegawai dan proses penilaian 
kinerja pegawai pada PDAM Tirta Patriot Kota Bekasi.

Penulis bertanya kepada admin yang paham tentang proses penilaian kinerja pegawai, dalam wawancara dengan beliau penulis dapat membahas mengenai proses penilaian pegawai secara manual. Dari hasil wawancara tersebut penulis menyimpulkan bahwa membutuhkan waktu untuk menilai kinerja pegawai dan membuat laporan tersebut. Hal ini diakibatkan oleh sistem pencatatan yang masih manual penggunaannya dalam penilaian pegawai berupa kertas formulir penilaian. Harapan beliau kedepannya sistem yang berjalan sudah terkomputerisasi sehinga mempunyai sistem penilaian kinerja untuk pegawai yang baik dan sistem dapat membuat laporan yang lebih efektif dan juga efisien.

Observasi adalah melakukan pengamatan dan pencatatan secara sistematik kepada unsurunsur yang muncul dalam suatu gejala dalam bentuk objek penelitian. Mendefinisikan observasi untuk memilih, mengubah dan juga pengodean serangkaian perilaku dalam susasana sesuai dengan tujuan empiris (Hikmat, 2011). Penulis melakukan observasi awal untuk mengumpulkan data-data yang dibutuhkan untuk analisa proses penilaian kinerja pegawai mulai bulan Maret.

\section{Langkah Pengembangan Sistem}

Pada tahapan analisis dan definisi kebutuhan penilaian kinerja penulis melakukan pengamatan terhadap sistem yang sedang berjalan dan konsultasi dengan admin bagian kepegawaian di PDAM Tirta Patriot mengenai masalah yang terjadi. Pada tahapan desain sistem dan perangkat lunak kinerja pegawai dibentuk rancangan berdasarkan persyaratan yang sudah ditetapkan oleh pihak

PDAM Tirta Patriot. Pada tahapan implementasi dan pengujian, hasil dari desain perangkat lunak direalisasikan sehingga program-program membentuk satu set program dan diuji sesuai dengan kebutuhan penilaian kinerja pegawai.

Pada tahapan integrasi dan pengujian sistem dilakukan untuk memastikan apakah semua fungsi sistem bekerja dengan baik dan mencari apakah masi ada kesalahan pada sistem. Pada tahap terakhir yaitu implementasi sistem dan pemeliharaan terdiri dari koreksi dari berbagai kesalahan yang tidak ditemukan di tahap-tahap sebelumnya, perbaikan atas implementasi dan pengembangan unit sistem, serta pemeliharaan program.

\section{Metode Penilaian Berbasis Loyalitas}

Metode penilaian kinerja yang digunakan di limgkungan PDAM TIRTA PATRIOT di kota Bekasi adalah metode penilaian berbasis loyalitas. Metode ini merupakan penilaian yang diberikan oleh atasan dengan tujuan untuk memperoleh bahan pertimbangan yang objektif dalam pembinaan pegawai, dan dilakukan dalam waktu sekali dalam setahun oleh pejabat penilai, yang sesuai dengan Daftar Penilaian Pelaksanaan Pekerjaan (DP3).

\section{Faktor Penyesuaian: Loyalitas}

Penilaian faktor penyesuian dilakukan oleh atasan dengan memilih salah satu hasil penilaian yang dinilai terhadap pegawai yang dinilai, penilaian berdasarkan pengamatan keloyalitasan pegawai berdasarkan kriteria : a) Baik $(1,05)$

Selalu menunjukan dan menjaga loyalitas terhadap perusahaan.

b) Cukup $(1,00)$

Adakalanya menunjukan loyalitas dengan patuh terhadap atasan, perusahaan dan ketentuan yang berlaku dalam perusahaan

c) Kurang $(0,95)$

Tidak menunjukan loyalitas dan tidak patuh terhadap atasan serta ketentuan yang berlaku dalam perusahaan.

\section{Perilaku Kerja}

Perilaku kerja merupakan sikap, tingkah laku, atau tindakan dilakukan oleh seorang pegawai yang seharusnya tidak dilakukan atau dilakukan sesuai dengan ketentuan peraturan yang berlaku. Adapun unsur perilaku kerja (beserta bobot penilaiannya) berdasarkan aturan yang telah ditentukan oleh perusahaan meliputi:

a) Prestasi Kerja (Bobot : 12,5\%)

b) Prakarsa (Bobot : 12,5\%)

c) Kerjasama (Bobot : 12,5\%)

d) Tanggung Jawab (Bobot : 12,5\%)

e) Moralitas (Bobot : 12,5\%)

f) Kejujuran (Bobot : 12,5\%)

g) Kehadiran (Bobot : 12,5\%)

h) Apel Pagi (Bobot : 12,5\%)

Hasil akhir dari penilaian kinerja, antara lain 
Tabel 1. Predikat Kinerja Pegawai

\begin{tabular}{|c|c|c|}
\hline \multicolumn{3}{|c|}{$\begin{array}{l}\text { Predikat Kinerja Pegawai (Individu) dan } \\
\text { Rekomendasi }\end{array}$} \\
\hline $91-100$ & $\begin{array}{l}\text { Sangat } \\
\text { Baik }\end{array}$ & $\begin{array}{l}\text { Sangat Direkomendasikan } \\
\text { Naik Pangkat / Golongan, } \\
\text { Berkala, Status, } \\
\text { Penyesuaian }\end{array}$ \\
\hline $76-90$ & Baik & $\begin{array}{l}\text { Direkomendasikan Naik } \\
\text { Pangkat / Golongan, } \\
\text { Berkala, Status, } \\
\text { Penyesuaian }\end{array}$ \\
\hline $61-75$ & Cukup & $\begin{array}{l}\text { Belum Direkomendasikan } \\
\text { Naik Pangkat / Golongan, } \\
\text { Berkala, Status, } \\
\text { Penyesuaian }\end{array}$ \\
\hline $51-60$ & Sedang & $\begin{array}{l}\text { Tidak Direkomendasikan } \\
\text { Naik Pangkat / Golongan, } \\
\text { Berkala, Status, } \\
\text { Penyesuaian }\end{array}$ \\
\hline$\leq 50$ & Kurang & $\begin{array}{l}\text { Tidak Direkomendasikan } \\
\text { Naik Pangkat / Golongan, } \\
\text { Berkala, Status, } \\
\text { Penyesuaian }\end{array}$ \\
\hline
\end{tabular}
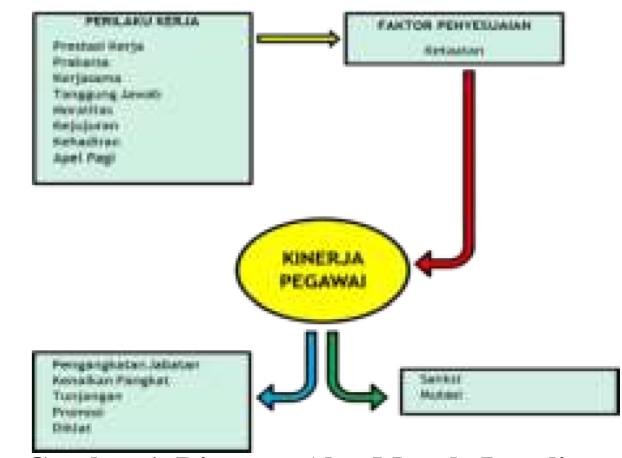

Gambar 1. Diagram Alur Metode Loyalitas

Contoh Perhitungan :

Misal Mr. X memiliki nilai prestasi kerja 90, nilai prakarsa 75 , nilai kerjasama 75 , nilai tanggung jawab 90 , nilai moralitas 75 , nilai kejujuran 90, nilai kehadiran 90, dan nilai apel pagi 75 .

Hasil nilai tersebut masing-masing dikalikan bobot sebesar $12.5 \%$ kemudian dijumlahkan :

$$
\begin{array}{ll}
\text { Prestasi Kerja } & =90 \times 12.5 \%=11.25 \\
\text { Prakarsa } & =50 \times 12.5 \%=6.25 \\
\text { Kerjasama } & =75 \times 12.5 \%=9.375 \\
\text { Tanggung Jawab } & =90 \times 12.5 \%=11.25 \\
\text { Moralitas } & =75 \times 12.5 \%=9.375 \\
\text { Kejujuran } & =90 \times 12.5 \%=11.25 \\
\text { Kehadiran } & =90 \times 12.5 \%=11.25 \\
\text { Apel Pagi } & =75 \times 12.5 \%=9.375
\end{array}
$$

Total nilai (nilai $\mathrm{x}$ bobot) dari $\mathrm{Mr}$. $\mathrm{X}$ adalah $=$ 79.375 .

Hasil total kemudian dikalikan dengan faktor penyesuaian yaitu ketaatan dari Mr. X yang bernilai 1,05 (Baik). maka : Total Nilai Akhir $=$ $79.375 \times 1.05=83.344$. Dengan hasil nilai ini Mr. X mendapatkan predikat kinerja pegawai Baik, karena berada di rentang nilai antara $76-$ 90. Maka Mr. X direkomendasikan naik pangkat/golongan, berkala, status, penyesuaian.

\section{HASIL DAN PEMBAHASAN}

Berdasarkan hasil analisa dan uraian umum tentang masalah-masalah yang dihadapi tersebut, maka alternatif dalam melakukan penilaian kinerja pegawai pada PDAM Tirta Patriot bekasi adalah membuat aplikasi sistem penilaian kinerja yang terkomputerisasi sehingga dapat dihasilkan informasi yang tepat, cepat dan akurat, data hasil penilaian bisa disimpan di hard disk sehingga dapat mengurangi pemakaian kertas, membuat aplikasi yang mudah digunakan dan dimengerti oleh admin bagian kepegawaian. Berikut adalah gambaran sistem yang diusulkan oleh penulis untuk PDAM Tirta Patriot Kota Bekasi.

Penulis menggunakan Diagram Alir Data (DAD) untuk merancang sistem penilaian kinerja di PDAM Tirta Patriot Bekasi. Menurut Ladjamudin (2013) "Diagram Alir Data merupakan model dari sistem untuk menggambarkan pembagian sistem ke modul yang lebih besar".

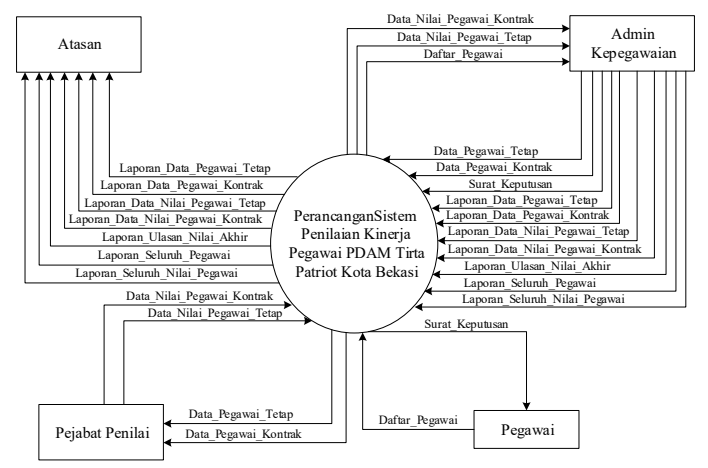

Gambar 2. Diagram Konteks yang Diusulkan

Hubungan antar data digambarkan dalam bentuk ERD (Entity Relationship Diagram). Menurut Ariani Sukamto \& Shalahuddin, (2015) pemodelan basis data yang paling banyak digunakan adalah menggunakan Entity Relationship Diagram (ERD). ERD digunakan untuk pemodelan basis data relasional. Tujuan dari ERD ini adalah menunjukkan objek data dan relationship yang ada pada objek tersebut. Adapun ERD untuk PDAM Tirta Patriot Bekasi adalah : 


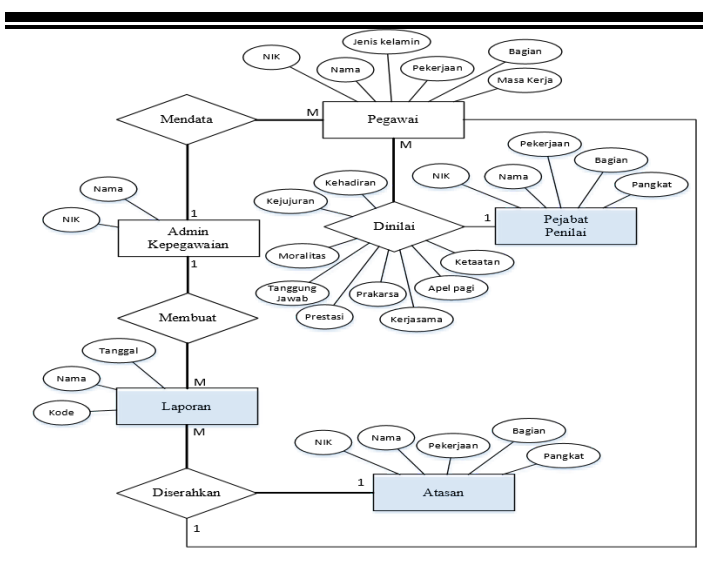

Gambar 3. Entity Relationship Diagram

Tampilan Login

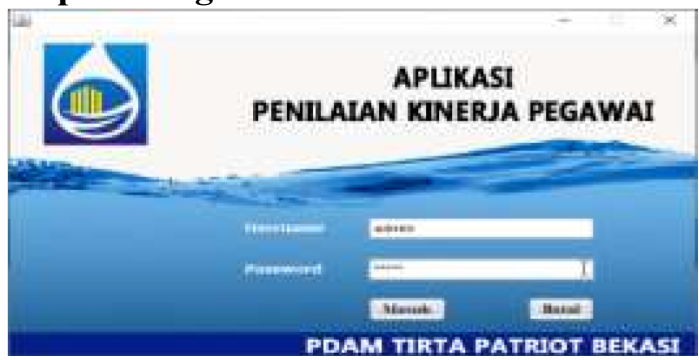

Gambar 4. Tampilan Login

Tampilan Login digunakan sebagai kunci utama agar tidak disalahgunakan oleh pengguna lain selain admin dan pejabat penilai.

\section{Tampilan Menu Utama}

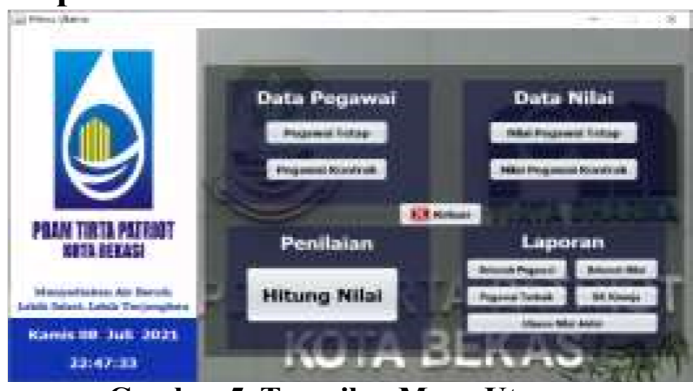

Gambar 5. Tampilan Menu Utama

Tampilan menu utama untuk mengakses berbagai menu yang ingin digunakan.

\section{Tampilan Form Pegawai Tetap}

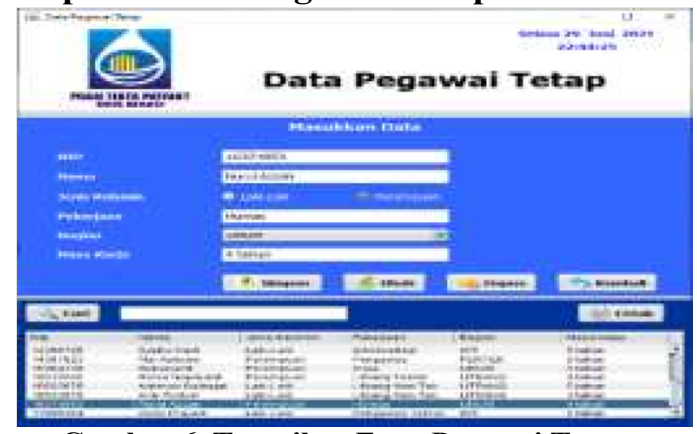

Gambar 6. Tampilan Form Pegawai Tetap
Untuk memasukkan nama pegawai tetap yang akan dinilai.

\section{Tampilan Form Pegawai Kontrak}

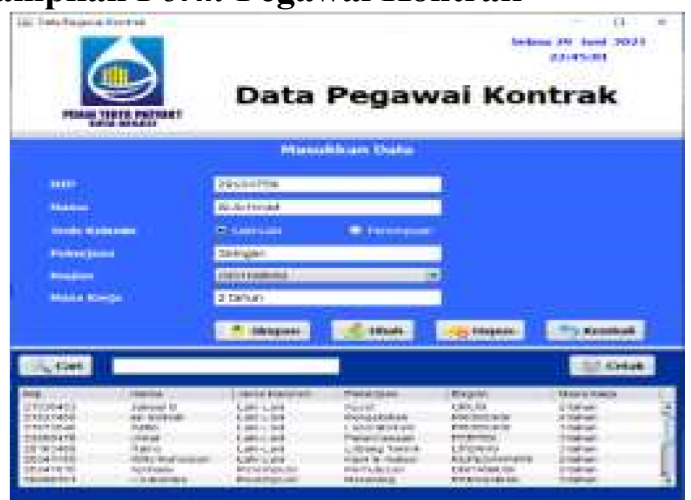

Gambar 7. Tampilan Form Pegawai Kontrak

Untuk memasukkan nama pegawai kontrak yang akan dinilai.

\section{Tampilan Form Nilai Pegawai Tetap}

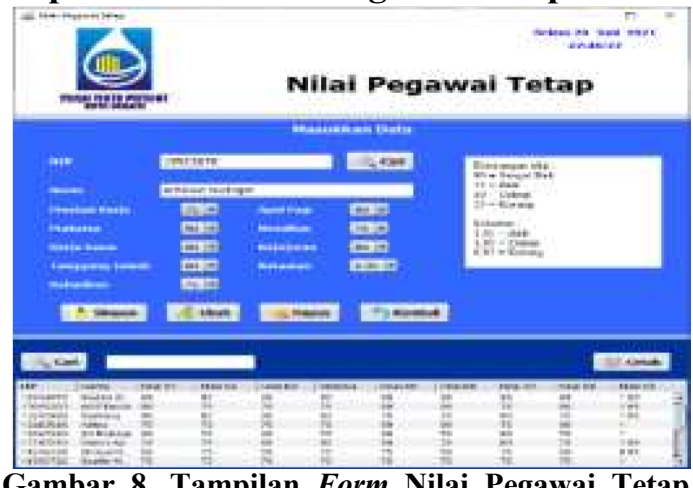

Gambar 8. Tampilan Form Nilai Pegawai Tetap Untuk memasukkan nilai pegawai tetap yang akan dinilai.

\section{Tampilan Form Nilai Pegawai Kontrak}

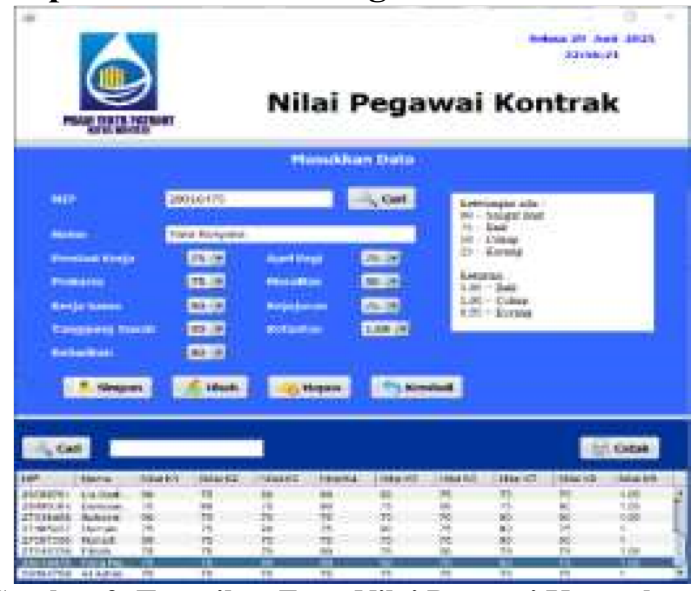

Gambar 9. Tampilan Form Nilai Pegawai Kontrak 
Untuk memasukkan nilai pegawai kontrak yang akan dinilai.

\section{Tampilan Form Perhitungan Nilai}

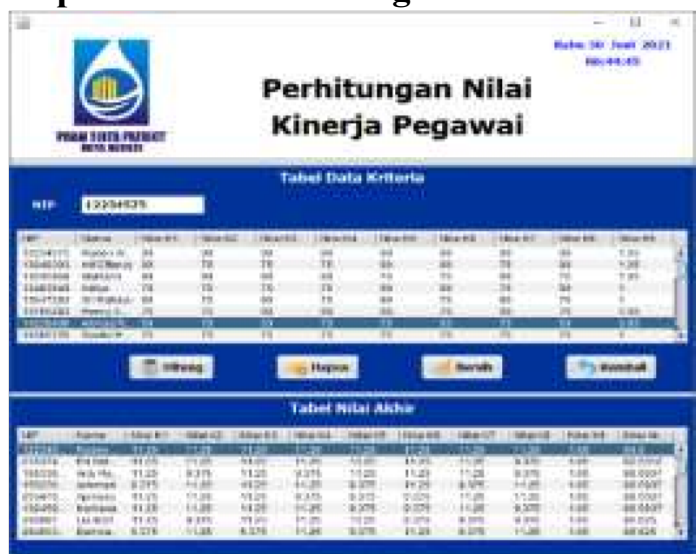

Gambar 10. Tampilan Form Perhitungan Nilai

Untuk memproses perhitungan nilai kinerja pegawai secara komputerisasi.

\section{Tampilan Laporan Seluruh Pegawai}

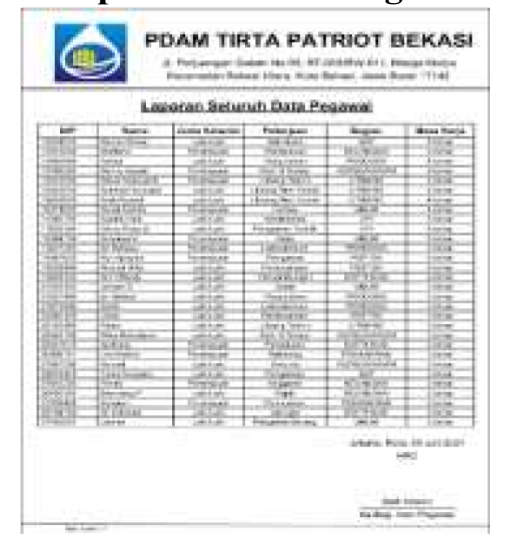

Gambar 11. Laporan Seluruh Pegawai

Tampilan Laporan data seluruh pegawai yang akan dilakukan penilaian kinerja.

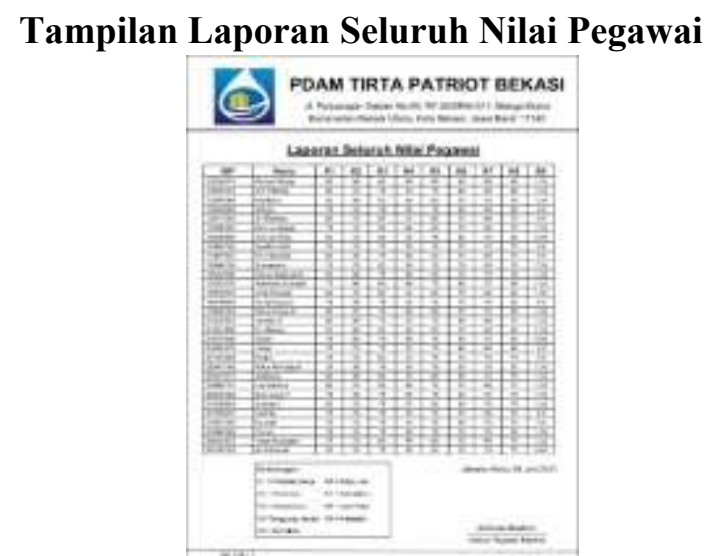

Gambar 12. Laporan Seluruh Nilai Pegawai
Tampilan Laporan data nilai seluruh pegawai yang telah dinilai kinerjanya oleh pejabat penilai.

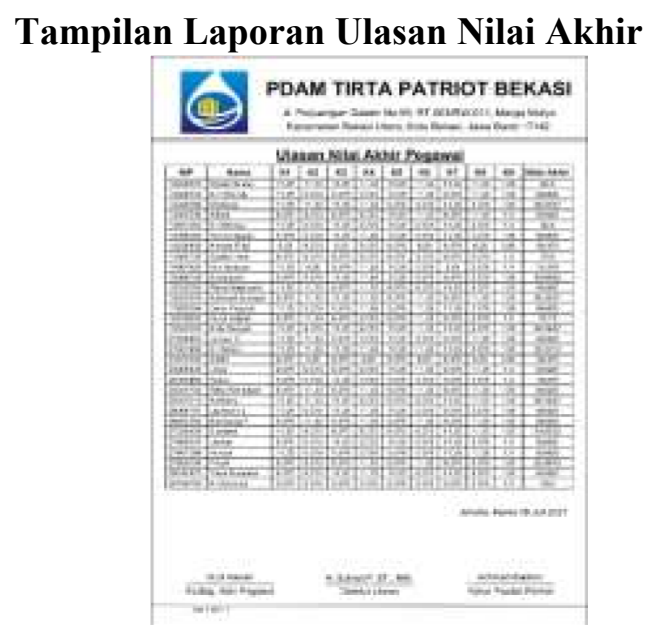

Gambar 13. Laporan Ulasan Nilai Akhir

Tampilan Laporan data ulasan nilai seluruh pegawai yang telah dihitung kinerjanya.

\section{Tampilan Surat Keputusan Pegawai}

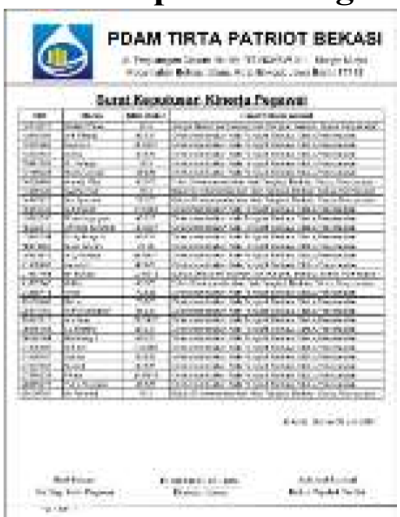

Gambar 14. Laporan Surat Keputusan Pegawai

Tampilan surat keputusan kepada seluruh pegawai yang telah dinilai kinerjanya. Sebagai rekomendasi Atasan dalam mengambil keputusan terhadap pegawai yang telah dinilai. Tampilan Surat Pegawai Terbaik 


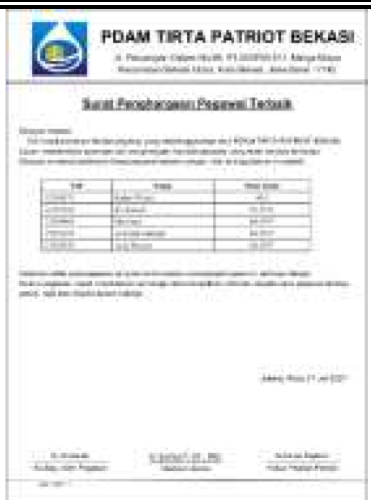

Gambar 15. Laporan Surat Pegawai Terbaik

Tampilan surat penghargaan kepada 5 (lima) pegawai terbaik yang telah dinilai kinerjanya.

\section{SIMPULAN DAN SARAN}

Berdasarkan hasil penelitian yang dilaksanakan, maka dapat disimpulkan beberapa hal mengenai sistem penilaian kinerja pegawai di PDAM Tirta Patriot Kota Bekasi adalah aplikasi Penilaian kinerja pegawai ini dirancang sebagai solusi bagi pihak PDAM Tirta Patriot Kota Bekasi untuk mengelola hasil nilai kinerja pegawai secara cepat, tepat dan akurat dibanding secara manual sehingga dalam mencapai pekerjaan dapat diselesaikan lebih maksimal.

Sistem yang dirancang dapat mengakomodasi kebutuhan dalam mempermudah dan mempercepat kinerja Admin Kepegawaian dan Pejabat Penilai yang bertugas dalam mengelola data menilai pegawai. Selain itu, penyimpanan data-data nilai pegawai dapat terorganisir dengan baik. Aplikasi Penilaian Kinerja ini dibuat bersifat intern, artinya pengguna yang menggunakan program ini untuk kalangan tertentu yang memiliki hak akses menggunakan aplikasi ini yaitu Atasan, Admin Kepegawaian dan Pejabat Penilai.

Agar penerapan sistem yang diusulkan ini dapat terwujud sesuai dengan harapan, maka penulis memberikan beberapa saran yang sebaiknya perlu diperhatikan : sebelum sistem baru dilaksanakan, sebaiknya Admin Kepegawaian dan Pejabat Penilai harus diberikan penjelasan sebaik-baiknya terlebih dahulu mengenai proses kerja sistem yang akan di terapkan, sehingga tidak terjadi kekeliruan dan kecanggungan dalam menggunakan aplikasi baru tersebut serta perlu dilakukan pelatihan penggunaan sistem tersebut agar mereka dapat mengetahui dan memahami cara kerja sistem yang baru.

Keamanan sistem harus dijaga dengan cara memberikan kepercayaan pada personil yang bisa bertanggung jawab. Meskipun sistem sudah terkomputerisasi, ketelitian dalam memasukkan data perlu diperhatikan agar data yang sudah disimpan benar-benar merupakan salinan dari data sumber. Sistem ini diharapkan dapat dikembangkan dan dimanfaatkan sebagaimana mestinya tanpa adanya penyalahgunaan pada informasi yang diberikan.

Penulis menyadari bahwa masih banyaknya kekurangan dalam pembuatan Aplikasi Sistem Penilaian Kinerja Pegawai pada PDAM Tirta Patriot di bekasi. Maka dari itu, penulis berharap sistem ini dapat dikembangkan lebih baik lagi dan mendapatkan saran yang lebih baik lagi.

\section{DAFTAR PUSTAKA}

Al-Bahra Bin Ladjamudin. (2013). Analisis dan Desain Sistem Informasi. Graha Ilmu.

Ariani Sukamto, R., \& Shalahuddin, M. (2015). Rekayasa Perangkat Lunak Terstruktur dan Berorientasi Objek.

Bandung : Informatika. informatika.

Fathansyah. (2012). Basis Data Edisi Revisi. Informatika.

Hikmat, M. M. (2011). Metode penelitian: dalam perspektif ilmu komunikasi dan sastra. Graha Ilmu.

Malayu S.P. Hasibuan. (2017). Manajemen Sumber Daya Manusia. In Edisi Revisi Jakarta: Bumi Aksara (Cet 7). Bumi Aksara.

Marwansyah. (2016). Manajemen Sumber Daya Manusia Edisi Kedua. In Alfabeta. CV Alfabeta.

Moeheriono, E., \& Si, D. M. (2012). Pengukuran Kinerja Berbasis Kompetensi. Jakarta: Raja Grafindo Persada.

Pressman, R. S. (2012). Rekayasa perangkat lunak:pendekatan praktisi ed.7. Andi.

Susanto, A. (2013). Sistem Informasi Akuntansi. Lingga Jaya.

Yakub. (2012). Pengantar sistem informasi. Graha Ilmu. 